\title{
Students' Variation in Translating English Passive Voice into Bahasa
}

\author{
Irwan Irwan', Hendra Eka Putra'2, Rahmadani Rahmadani ${ }^{3}$ \\ ${ }^{1}$ Institut Agama Islam Negeri Batusangkar, Indonesia. E-mail: irwan@iainbatusangkar.ac.id \\ 2Institut Agama Islam Negeri Batusangkar, Indonesia. E-mail: hendraep@iainbatusangkar.ac.id \\ 3Institut Agama Islam Negeri Batusangkar, Indonesia. E-mail: rahmadani@iainbatusangkar.ac.id
}

\begin{tabular}{l} 
ARTICLE INFO \\
\hline Keywords: \\
Variation; Translating; \\
Passive Voice \\
\\
How to cite: \\
Irwan, I., et. al. (2018). \\
Students' Variation in \\
Translating English \\
Passive Voice into Bahasa, \\
4(2), 91-105. \\
DOI: \\
http://dx.doi.org/10.31332/ \\
lkw.v4i2.897
\end{tabular}

\begin{abstract}
This article was focused on analyzing students' variation in translating English passive voice into Bahasa Indonesia. The datawas taken from the final examination results of Translation I subject. There were91 documents. Data were analyzed based on the theory of translation variation. There were 137 translation variations found in students' translation results. The variations of students' translations were "(had) being banned" 8 translated variation, "was brought down in" 13 translated variation, "be sentenced" 7 translated variations, "(is) given by" 7 translated variations, "were convicted of" 7 translated variations, "were embroiled in" 5 translated variations, "was placed under" 7 translated variations, "is sponsored by" 4 translated variations, "(was) exposed by" 17 translated variations, "had been covered up by" 5 translated variations, "was banned from" 5 translated variations, "were excluded from" 5 translated variations, "have never been convicted of" 7 translated variations, "(was) banned for" 5 translated variations, "was not suspended" 11 translated variations, "have been banned for" 4 translated variations, "was charged over" 4 translated variations, "were investigated" 2 translated variations, "was caught up in" 4 translated variations. It can be concluded that the students' translation skill especially in translating passive voice still have problem and it should be developed as well as possible.
\end{abstract}

\section{Introduction}

Nowdays, having ability in translation becomes a primary necessity for students who learn language especially foreign language. But, Translation has become one of the ways of learning languages since a long time ago. In Indonesia for example, English is taught as a foreign language. Today, many sources or learning materials are provided by a lot of experts, and most of them are written in English. The ability in translation is very useful to help students in understanding those material such article, journal, essay or even a textbook. Indeed, translation has often been defined with reference to meaning (Gunawan, 2015). According to Larson, translation is the replacement of meaning from a source language into a target language (Larson, 1984). The differences of grammatical structures between source and target language often result in some change in the meaning during the process of 
translation. A student that also as a translator must comprehend both the structure of source and target language well because a translation is not simply a matter of different word choice, but also as different grammatical structures as well.

One of aspects in grammar that a translator should study is passive voice. The meaning of passive voice can also be combined with another factor such as unintended factor. When an active is changed into passive that meaning contained by the verb, and the action is unintended, so the prefix used is ter-instead of $d i$.

In English Department of IAIN Batusangkar, there is a Translation subject in fifth semester. It is a pre-requisite subject for the students before coming to the next semester. Meanwhile, they also have learned about passive voice in Grammar subject on the fourth semester and to be continued on the fifth semester. Based on the observation toward the researchers' experience as a lecturer and also it has continued to the next students, there are some phenomena appeared. Those are like the problems in translating passive voice into Target Language (TL) correctly and also the varieties of structure and meaning in translating passive voice into TL. Besides, they have already learned about passive voice in the previous semester. The researcher found some examples of student's translating passive voice into Bahasa Indonesia. For example:

(Source Language)

"The user should shut down the computer before placing the laptop in its carrying bag since the laptop can melt when left on, particularly when the notebook is placed in a container where no air or limited air is allowed to circulate."

(Target Language)

"Pengguna harus mematikan komputer sebelum memasukkan laptop di dalam tas karena laptop bisa meluluhkan ketika ditinggalkan, terutama ketika notebook ditempatkan dalam sebuah wadah di mana tidak ada udara atau udara terbatas diperbolehkan beredar."

From the text above, the writers found some translating result into bahasa Indonesia from passive sentence in English. It was dominantly translated into bahasa Indonesia by using prefix di- and suffix -kan. This translation looks like translating by word for word translation. The writers concluded that the student could make the other result of translation without transfering all of meaning by word for word. The passive voice "is placed" should not be translated "ditempatkan"butitwas translated diletakkan. It would make the meaning and translation result sound naturally in Bahasa Indonesia.

Before analyzing the students' translation let see several theories of translation and passive voice first. There are many definitions of translation. Larson states that translation is a process which involves activities such as studying lexicon, grammatical structure, communication situation, and cultural context of the source language text (Larson, 1984). Catford also defines translation as the replacement of textual material in one language (source language or SL) by equivalent textual material in another language (target language or TL) (Catford, 1965). To complete Catford's definition, Bassnett explains that translation as a process that involves the delivering of a source language (SL) text into the target language (TL) so as to ensure 
that the surface meaning of the two languages will be approximately similar and the structures of the SL will be preserved as closely as possible but not so closely that the Target Language structures will be seriously distorted (Bassnett, 2013).

Besides that, there are also types of translation, principles of translation and translation process that should be discussed to guide our analysis. Regarding to Larson, there are two main kinds of translations (Larson, 1984). One is form-based and the other is meaning-based translation. Form-based translations attempt to follow the form of the source language and are known as literal translations. It lay on between word-for-word and free translation (Nababan, 1999). The structure of TT is modulated with the structure of target language. It is appropiate to translate a text which have a few similiraties of grammatical form between two languages.

Talking about principles of translation, Duff in Zulhermindra says that a translator should know some general principles of translation. They are (1) meaning; the translation should reflect the meaning of the original text accurately, (2) Form; the translation should be matched the ordering words and ideas as closely as possible to the original text, (3) Register; the different of formally of language in a given context, (4) Source language influence in which the translator should be aware of the difference of the two languages which might influence the translation that make translation does not sound natural, (5) Style and clarity; the translator should not change the style of the source text and(6) idiomatic expression used by the source language that might not be found or expressed differently in target language (Zulhermindra, 1996).

Furthermore, the model of Nida and Taber in Irma in the process of translation above can be explained as follows (Nida \& Taber, 2003):

a) A translator reads over the text that refers to the SL document which is to be translated and understands the meaning and the message of the text. It will be much better to read the passage twice or three times in order to get a clear grasp of the entire content.

b) This phase is the process of discovering the meaning of SL which is to be translated. In the attempt to understand the whole content of the text, a translator has to conduct linguistic analysis either grammatical or meaning analysis.

c) Transfer discusses how the analysis result is transferred from the source language to the target language with the least possible change in meaning. In this phase, after finishing the analysis of the text and understanding the source message, then a translator transfers the message into target language.

d) Nida and Taber tell about restructuring as follows: "Restructuring, in the translated material, is restructured in order to make the final message fully acceptable in the receptor language" (Nida \& Taber, 2003). After the translator analyzes the text and understands the message of the text, he starts to restructure the text in the target language. This stage is done to check for the naturalness and accuracy of his translation result. The translator has to maintain the message of the original text in his translation and he should obey the target language grammar rules. 
After discussing the theories of translation, it is a must for us to discuss about the definition of passive voice because the data in this research were passive voice sentences. Murphy writes that in a passive sentence if you want to say who did or what caused the action, use by. Passive voice denotes that the subject receives the action. The active voice is used when the verb is in the active voice, the person or thing denoted by the subject is said to do something; as I love. Passive voice is used when the verb is in the Passive Voice, the person or thing denoted by the Subject is said to suffer something; as I am loved. The verb of the English passive voice is always preceded by one of the 'be' forms followed by past participle verb (Murphy, 2003).

Moreover, Azar says that the object an active sentence becomes the subject of a passive sentence and the subject of an active sentence is the object of by in the "byphrase" in a passive subject (Azar \& Azar, 1999). Walsh argues that The voice of a verb indicates whether the subject of the verb acts or is acted upon. Active voice denotes that the subject of the verb is the actor. Passive voice denotes that the subject receives the action (Walsh \& Walsh, 1972). In addition, Frank points out that the passive voice is preferred when the "doer" of an action (or, the agent) is unimportant or unknown (Frank, 1972).

How to use passive voice? Frank in Elvi points out that Passive Voice is used to the sentence that the subject is not necessary to know (Frank, 1972). Therefore, because of its impersonal tone, the passive voice is commonly found in textbook, in scientific, technical or business reports, and in newspaper stories. Eckersley states that we use the Passive Voice when we are more interested in the action than in the person or people who do the action. Murphy comments the using of passive that (Murphy, 2003):

a) We use an active verb to say what the subject does, as in:

- My grandfather was a builder. He built this house in 1930.

- It's a big company. It employs two hundred people.

b) We use a passive verb to say what happens to the subject, as in:

- This house is quite old. It was built in 1930.

- Two hundred people are employed by the company.

Then, Azar states about the forms of passive voice and also the rules of making passive voice that is (Azar \& Azar, 1999):

a) The object of an active sentence becomes the subject of a passive sentence, as in:

$\mathrm{S}+\mathrm{V}+\underline{\mathrm{O}}=$ Bob mailed the letter

The letter was mailed by Bob (by-phrase)

b) All the passive verbs are formed with $\underline{\mathrm{Be}}+$ Past Participle.

- "Be" can be in any of its forms:

am, is, are, was, were, has been, have been, will be,etc.

- The Past Participleis followed by Be. For regular verbs, the past participle ends in -ed (e.g., mailed, corrected). Some past participles are irregular (e.g., taught), as in

Active: The news surprised me

Passive: I was surprised by the news 
c) Only transitive verbs can be used in the passive. A transitive is a verb that is followed by an object, as in :

$\begin{array}{llll}\mathrm{S} & \mathrm{V} & \mathrm{O} & \\ \mathrm{Bob}+ & \text { mailed } & + & \text { the letter } \\ \mathrm{Mr} \text {. Lee }+ & \text { signed } & + & \text { the check } \\ \text { A cat }+ & \text { killed }+ & \text { the bird }\end{array}$

An intransitive verb is a verb that is not followed by an object, an intransitive cannot be used in the passive, as in:

$\begin{array}{lll}\text { S } & \text { V } & \\ \text { An accident+ } & \text { happened } & \\ \text { John+ } & \text { came } & \text { to our house } \\ \text { I+ } & \text { slept } & \text { well last night }\end{array}$

According to Azhar "be" can be followed by an adjective. The past participle is often like an adjective that describes or gives information about the subject of the sentence. Past participles are used as adjectives in many common and everyday expressions. The past participles in this expression are often followed by particular prepositions + an object, for example: Paul is married to Susan ("married" is followed by "to" + an object).

There are some common expressions with "be+past participle" as follow on table below:

\begin{tabular}{|l|l|l|}
\hline be acquainted (with) & be excited (about) & be opposed (to) \\
be bored (with, by) & be exhausted (from) & be pleased (with) \\
be broken & be finished (with) & be prepared (for) \\
be closed & be frightened (of, & be qualified (for) \\
be composed of & by) & be related (to) \\
be crowded (with) & be gone (from) & be satisfied (with) \\
be devoted (to) & be hurt & be scared (of, by) \\
be disappointed (in, with) & be interested (in) & be shut \\
be divorced (from) & be involved (in) & be spoiled \\
be done (with) & be located (in) & be terrified (of, by) \\
be drunk (on) & be lost & be tired (of, from) \\
be engaged (to) & be made of & be worried (about) \\
& be married (to) & \\
\hline
\end{tabular}

Translating the passive voice is not too different with translating the other grammatical form. The important point is how the translator transfers the meaning of source language into target language that is accepted by the receptor understanding. As Beekman and Callow point out in Baker that translators sometimes translate passive voice automatically, without seeing and respecting the linguistic pecularity of the SL and TL which resulting the unnatural translation (Baker, 2011).

Even though the linguistic category of voice exists in both the source and the target language, it might be a different role and have a different significance in the two languages. First, the passive voice might be used with different frequency in the source and the target language, as Baker claims, "languages which have a category of voice do not always use the passive with the same frequency" (Baker, 2011). There 
are even languages which simply have no passive and all the passive forms that appear in the languages with the passive voice have to be changed into active forms in the translations.

Vina states that in bahasa Indonesia, active verbs may be transitive or intransitive. Transitive can be marked by prefix me - or its variation such as men -, meng -, me -kan and me-i. The examples are: (1) Rakyat pasti mencintai pemimpin yang jujur, (2) Saya suka menonton televisi, and (3) Dia akan mengambil uang di bank. The example of active intransitive as follow: (1) Kita harus bekerja keras untuk membangun Negara, (2) Saya ingin berjalan kaki saja. (Suprato, 2013)

To transform from an active into passive as follows:

a. Making the object of the active sentence become the subject of the passive sentence;

b. Replacing the prefix me- with di-, ter-, or ke - an.

c. Making the subject of the active sentence become the agent, recipient of the passive form signalled by the preposition oleh (by) which may be left out if the doer is obvious or unimportant.

The former researcher Vina has discussed only about the replacing prefix mewith di, ter or ke- an (Suprato, 2013). She did not discuss the variation of the translation itself. She also explained how to transform from an active into passive voice.

In this research the writer analyzed and exposed the variation of the translation itself because the variation emerged differently from the same text. It must be the same translation from the same text but the fact showed that they were different. The question of why could be? It was a challenging to be answered.

\section{Method}

This research was a qualitative method by using content analysis that will find out students' variation in translating English passive voice into bahasa Indonesia. According to Gay, qualitative research is the collection, analysis and interpretation of comprehensive narrative and visual (i.e., non- numerical) data to gain insights into a particular phenomenon of interest (Gay, Mills, \& Airasian, 2009). In this research, the researcher analyzed students' variation in translating English passive voice into bahasa Indonesia.

Then, Chelimsky states that "Content analysis is a set of procedures for collecting and organizing information in standardized format that allows analysis to make inferences about characteristics and meaning of written and other recorded material"(Chelimsky, 1989). Moreover, Arikunto states that the final conclusion of descriptive study should be in words or sentences, not in a number (Arikunto, 2010). Dealing with the theories above, the researcher used descriptive qualitative research, especially content analysis to describe Students' Variation in Translating Verb Phrase of English Department at IAIN Batusangkar.

In analyzing the document, the researcher use Chelimsky points out six steps in conducting content analysis. Those steps are (Chelimsky, 1989):

a) Deciding to use the content analysis

To beginning the research that using content analysis, the researcher will formulate the question first. The question must be clear understanding of project 
needs and available data. Chelimsky states that the content analysis can be used to answer the question "what" (Chelimsky, 1989). This research is formulated by usisng the question of "what" as states in the research question that is "what are students variation in translating passive voice. It means that the content analysis is appropriate to be used in this research.

b) Determining what material should be included in content analysis

The next step of content analysis is about choosing the material. Material of the research must be done and it can be use appropriate sample technique. In this research researcher will use total sampling to choosing- the data should be analyzed. Therefore, the researcher used all of the document to analyzed the students variation in translating english passive voice.

c) Selecting unit analysis

In content analysis, there are two unit analyses such as content unit and recording unit. The content unit is a unit set limits of written material that is to be examined. While recording unit is the specific part of the content unit in the written material that is placed in category. In this research the content analysis unit was students variation in translating passive voice. Then, the recording unit was passive voice that contain in the text.

d) Developing the coding categories

According to Chelimsky, categories provide the structure for grouping document unit (Chelimsky, 1989). It means the researcher would code all of passive voice that found in the documents. First, the researcher determined the codification to all of the documents like D1 for document 1 until D91. Second, the researcher determined the codification to all the passive voice that found in the source text like S1 for the first passive voice in the text until S20 for the twentith passive voice. Then, the researcher gave codes for each translation results of English passive voice into Bahasa Indonesian. The coding was done for each documents. The codes were PT1 (First Passive Voice Translated in Target text), PT2 (Second Passive Voice Translated in Target text), PT3 (Third Passive Voice Translated in Target text) and so on until PT20.

e) Coding the material

In this step, researcher would code all of the document that is used by the the fifth semester students who had taken translation subject. The researcher would also underline the position all of passive voice that are found in the target text as the document also. It is used to make the researcher and reader understand the analysis.

f) Analyzing and interpreting the result

In the last step of the content analysis, the researcher would analyze passive voice that translated by the students. The first thing will be done by the researcher in analyzing the data was checking the student translation several times. Then, he would identify the way the students translate passive voice by using document that translating by the students that the result was acceptable or unaccaptable to include as the one of student's variation in translating English passive voice into Bahasa Indonesian. Then, the researcher would classify what the students' variation in translating passive voice. 


\section{Findings and Discussion}

The data of this research were 20 passive voice that was found in the source text as the students' translation examination in Translation I. It was included of passive verb (transitive) and stative passive. As reminder, Azhar explains that all passive verb are formed with $B e+$ Past Participle. There were 14 stative passive and 6 passive verb (transitive) that were found from the data. The data sources of this study was taken from the final examination results of Translation I subject of the fifth semester student as counted 91 documents.

There were 137 translation variations after analyze the translation results of students. The variations of students' translations were "(had) being banned" 8 translated variation, "was brought down in" 13 translated variation, "be sentenced" 7 translated variations, "(is) given by" 7 translated variations, "were convicted of" 7 translated variations, "were embroiled in" 5 translated variations, "was placed under" 7 translated variations, "is sponsored by" 4 translated variations, "(was) exposed by" 17 translated variations, "had been covered up by" 5 translated variations, "was banned from" 5 translated variations, "were excluded from" 5 translated variations, "have never been convicted of" 7 translated variations, "(was) banned for" 5 translated variations, "was not suspended" 11 translated variations, "have been banned for" 4 translated variations, "was charged over" 4 translated variations, "were investigated" 2 translated variations, "was caught up in" 4 translated variations and "had been banned for" 5 translated variations.

To make it clear, the findings were elaborated in the table as follows:

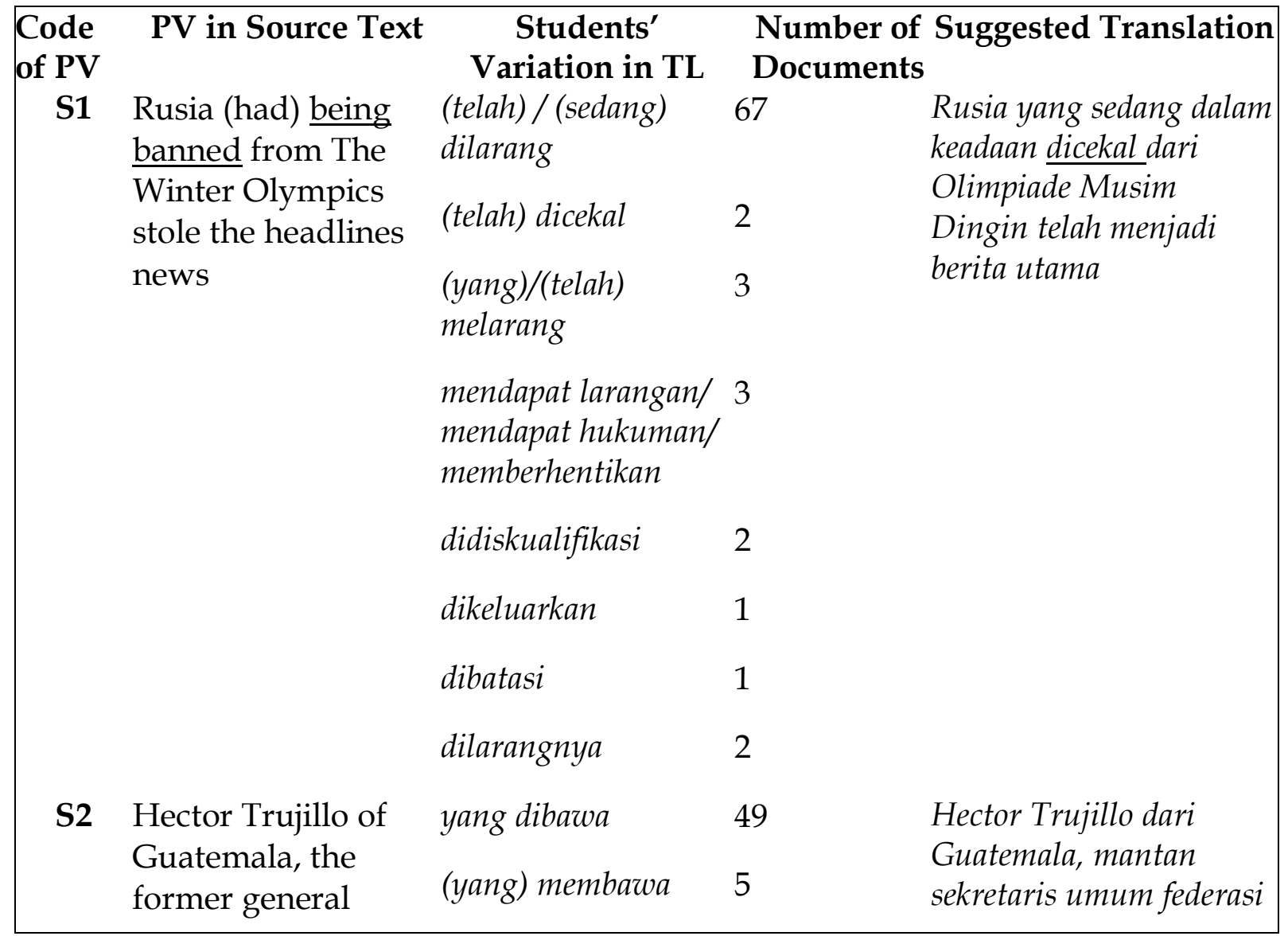




\begin{tabular}{|c|c|c|c|c|}
\hline & $\begin{array}{l}\text { secretary of his } \\
\text { country's football } \\
\text { federation, was the } \\
\text { first person brought } \\
\text { down in ** the wide } \\
\text { spread FIFA } \\
\text { Corruption }\end{array}$ & $\begin{array}{l}\text { terlibat } \\
\text { terjun } \\
\text { terguling } \\
\text { (yang) diketahui } \\
\text { (yang) menjatuhkan } \\
\text { tertangkap } \\
\text { digiring } \\
\text { termasuk } \\
\text { terseret } \\
\text { terjatuh } \\
\text { diturunkan }\end{array}$ & $\begin{array}{l}1 \\
1 \\
6 \\
1 \\
1 \\
1 \\
1\end{array}$ & $\begin{array}{l}\text { sepak bola negaranya, } \\
\text { adalah orang pertama } \\
\text { yang dibawa dalam } \\
\text { skandal korupsi FIFA } \\
\text { yang meluas }\end{array}$ \\
\hline S3 & $\begin{array}{l}{ }^{* *} \text { the widespread } \\
\text { FIFA corruption } \\
\text { scandal to be } \underline{\text { sentenced to jail, }} \\
\text { s* }\end{array}$ & $\begin{array}{l}\text { dijatuhi (hukuman) } \\
\text { dihukum } \\
\text { dihakimi } \\
\text { dipenjarakan } \\
\text { diberikan } \\
\text { divonis } \\
\text { dimasukkan }\end{array}$ & $\begin{array}{l}59 \\
8 \\
1 \\
2 \\
2 \\
1 \\
1\end{array}$ & $\begin{array}{l}\text { ** skandal korupsi FIFA } \\
\text { yang meluas sehingga } \\
\text { dijatuhi hukuman } \\
\text { penjara }^{* *}\end{array}$ \\
\hline S4 & $\begin{array}{l}{ }^{* *} \text { (was) given eight } \\
\text { months by a judge }\end{array}$ & $\begin{array}{l}\text { yang diputuskan } \\
\text { diberikan } \\
\text { diberi } \\
\text { dijatuhi } \\
\text { dihukum } \\
\text { mendapat(kan) } \\
\text { putusan } \\
\text { dijatuhkan }\end{array}$ & $\begin{array}{l}46 \\
6 \\
8 \\
1 \\
2 \\
2\end{array}$ & $\begin{array}{l}\text { ** dijatuhi hukuman } \\
\text { penjara selama delapan } \\
\text { bulan oleh hakim }\end{array}$ \\
\hline S5 & $\begin{array}{l}\text { Juan Angel Napout, } \\
\text { former head of } \\
\text { Paraguayan }\end{array}$ & $\begin{array}{l}\text { dihukum } \\
\text { (telah) dijatuhi }\end{array}$ & 74 & $\begin{array}{l}\text { Juan Angel Napout, } \\
\text { mantan kepala sepakbola } \\
\text { Paraguay, dihukum }\end{array}$ \\
\hline
\end{tabular}




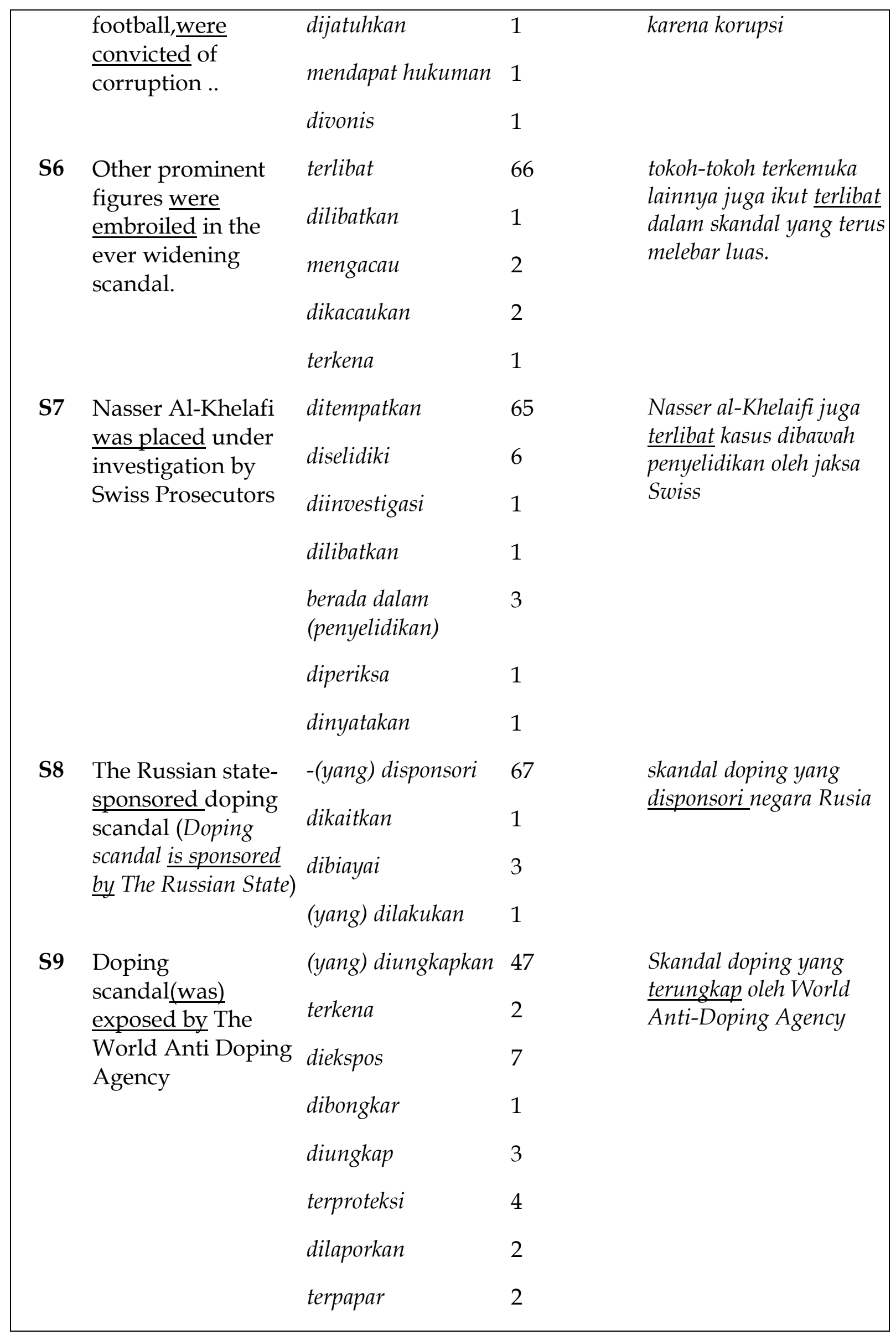




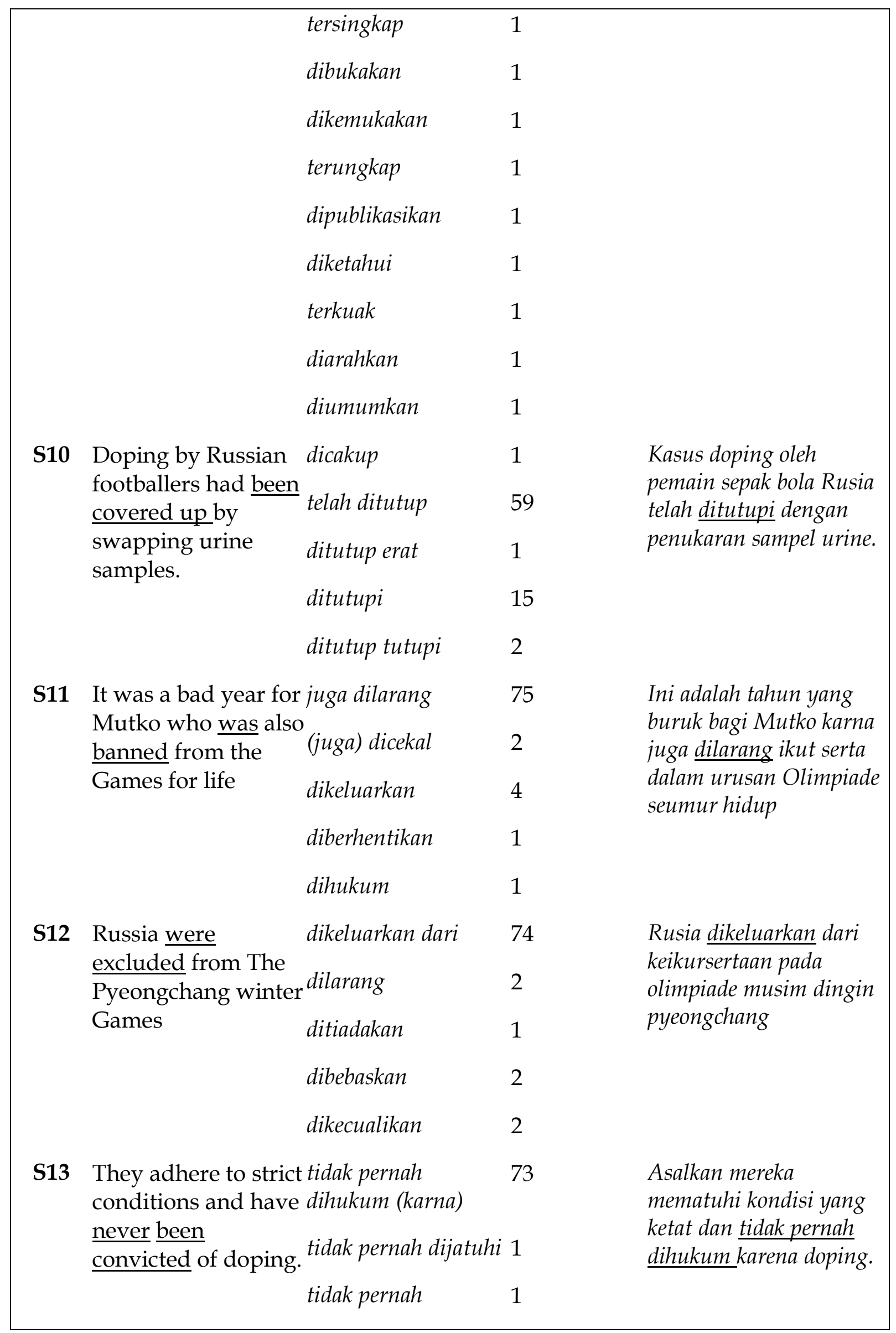




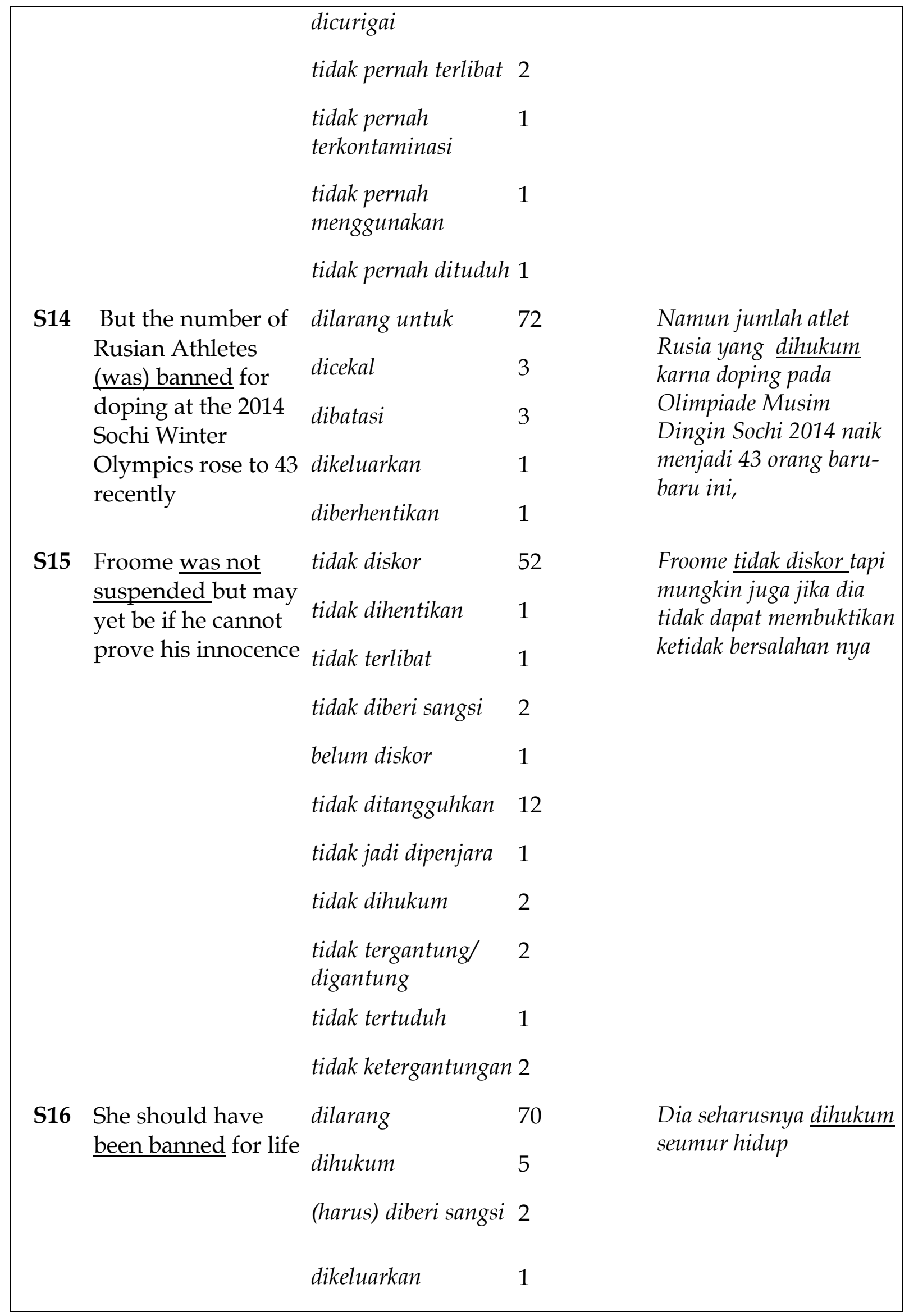




\begin{tabular}{|c|c|c|c|c|}
\hline \multirow[t]{9}{*}{ S17 } & \multirow[t]{9}{*}{$\begin{array}{l}\text { He was charged } \\
\text { over a } 2 \text { million } \\
\text { dollars vote buying } \\
\text { scandal. }\end{array}$} & $\begin{array}{l}\text { dikenai hukuman } \\
\text { dituduh atas } \\
\text { menyimpan }\end{array}$ & 52 & \multirow[t]{9}{*}{$\begin{array}{l}\text { Dia dikenai hukuman } \\
\text { atas skandal pembelian } \\
\text { hak suara senilai } 2 \text { juta } \\
\text { dolar. }\end{array}$} \\
\hline & & dijatuhi hukuman & 2 & \\
\hline & & didenda & 1 & \\
\hline & & dihukum & 10 & \\
\hline & & bertanggung jawab & 1 & \\
\hline & & dituduh & 1 & \\
\hline & & dibebankan & 2 & \\
\hline & & dikenakan & 2 & \\
\hline & & didakwa & 1 & \\
\hline S18 & $\begin{array}{l}\text { Papa Masata were } \\
\text { also investigated as } \\
\text { authorities in France }\end{array}$ & diinvestigasi & 77 & $\begin{array}{l}\text { Papa Massata juga } \\
\text { diselidiki saat pihak } \\
\text { berwenang di Prancis }\end{array}$ \\
\hline \multirow[t]{3}{*}{ S19 } & \multirow[t]{3}{*}{$\frac{\text { was caught up in the }}{\text { affair }}$} & $\begin{array}{l}\text { terjebak } \\
\text { terperangkap }\end{array}$ & 70 & \multirow[t]{3}{*}{$\begin{array}{l}\text { Frankie Fredericks } \\
\text { tersandung dalam kasus } \\
\text { perselingkuhan }\end{array}$} \\
\hline & & ditangkap & 7 & \\
\hline & & Tertangkap & 3 & \\
\hline \multirow[t]{3}{*}{ S20 } & $\begin{array}{l}\text { Two Diacks had } \\
\text { already been bannec } \\
\text { for life by IAAF }\end{array}$ & $\begin{array}{l}\text { (telah) dilarang } \\
\text { Dihukum }\end{array}$ & 75 & \multirow{4}{*}{$\begin{array}{l}\text { Kedua anggota keluarga } \\
\text { Diack tersebut telah } \\
\text { dilarang keikursertaanya } \\
\text { selama seumur hidup } \\
\text { oleh IAAF }\end{array}$} \\
\hline & & dijatuhi sangsi & 3 & \\
\hline & & $\begin{array}{l}\text { mendapatkan } \\
\text { (hukuman) } \\
\text { diherhentikan }\end{array}$ & 1 & \\
\hline \multicolumn{3}{|c|}{ Total of Variation } & 137 & \\
\hline
\end{tabular}

\subsection{Discussion}

Based on research finding above, it gave the information that students have many variations in translating English text especially in translating passive voice. Indeed, they were allowed to try the other translation results as far as the meaning is appropriate with the source meaning. Beside that, most of the students translated the passive voice into bahasa Indonesian based on the textual meaning in the dictionary generally without making the improvisations of using word choice in Indonesian. 
Furthermore, students' background knowledge also influenced the result of translation itself. Cultural transfer (in first language) gave a negative side effect to their translation which have a different way of how to write the sentences in passive voice.

This discussion showed us the theory of cultural background has significant influence toward translation product. Classen said from the perspective of translation itself quickly leads to transcultural activities since making ides, thoughts, concepts and texts (Classen, 2012).

\section{Conclusion}

Based on research findings, the researcher found twenty forms of passive voice in the source text. It was included passive verb and static passive. There were 137 students' variation results in translating English passive voice into bahasa Indonesia. At least, each passive voice had more than two variations in English passive voice translations. The variations of students' translations were "(had) being banned" 8 translated variation, "was brought down in" 13 translated variation, "be sentenced" 7 translated variations, "(is) given by" 7 translated variations, "were convicted of" 7 translated variations, "were embroiled in" 5 translated variations, "was placed under" 7 translated variations, "is sponsored by" 4 translated variations, "(was) exposed by" 17 translated variations, "had been covered up by" 5 translated variations, "was banned from" 5 translated variations, "were excluded from" 5 translated variations, "have never been convicted of" 7 translated variations, "(was) banned for" 5 translated variations, "was not suspended" 11 translated variations, "have been banned for" 4 translated variations, "was charged over" 4 translated variations, "were investigated" 2 translated variations, "was caught up in" 4 translated variations and "had been banned for" 5 translated variations.

\section{References}

Arikunto, S. (2010). Prosedur Penelitian Pendekatan Praktik Edisi Revisi VI. (VI). Jakarta: Rineka Cipta.

Azar, B. S., \& Azar, D. A. (1999). Fundamentals of English Grammar. New Jersey (2nd ed.). New Jersey: Prentice Hall. https://doi.org/10.1002/15213773(20010316)40:6<9823::AID-ANIE9823>3.3.CO;2-C

Baker, M. (2011). In other words: A coursebook on translation. New York: Routledge.

Bassnett, S. (2013). Translation studies (3rd ed.). New York: Routledge.

Catford, J. C. (1965). A linguistic theory of translation: An essay in applied linguistics. Oxford: Oxford University Press.

Chelimsky, E. (1989). Content analysis: a methodology for structuring and analyzing written material. Office, USGA (Ed.).

Classen, A. (2012). Translation as the Catalyst of Cultural Transfer. Molecular Diversity Preservation International.

Frank, M. (1972). Modern English: a Practical Reference Guide. New Jersey: Prentice Hall. 
Gay, L. R., Mills, G. E., \& Airasian, P. W. (2009). Educational research: Competencies for analysis and applications, student value edition. USA: Upper Saddle River, NJ: Merrill.

Gunawan, F. (2015). تحليل الأخطاء النحوية فى نرجمة كتاب نصائح العباد (الدراسة فى نقد الترجمة) Langkawi: Journal of The Association for Arabic and English, 1(1), 71-84.

Larson, M. L. (1984). Meaning-based translation: A guide to cross-language equivalence. University press of America Lanham.

Murphy, R. (2003). English Grammar in Use: A self-study reference and practice for intermediate students/R. United Kingdom: Cambridge University Press.

Nababan, R. (1999). Teori Menerjemah Bahasa Inggris. Yogyakarta: Pustaka Pelajar.

Nida, E. A., \& Taber, C. R. (2003). The theory and practice of translation (Vol. 8). Leiden: Brill.

Suprato, D. (2013). Analisis Penerjemahan Kalimat Pasif Bahasa Inggris Ke dalam Bahasa Indonesia pada Novel Morning, Noon and Night Karya Sidney Sheldon. Lingua Cultura, 7(1), 49-56.

Walsh, J. M., \& Walsh, A. K. (1972). Plain English Handbook. Ohio: McCormik-Mathers Publishing.

Zulhermindra. (1996). A Pragmatic Analysis on Students Translation of English Term of Address into Indonesian. Padang: IKIP Padang. 